\title{
SERUM PROTEIN FRACTIONS OF MICE INFECTED WITH MURINE LEPROSY
}

\author{
Kiyo SUSHIDA \\ (Tokyo Women's Medical College)
}

Mice were inoculated with murine leprosy bacilli (Hawaiian strain) and the protein, lipoprotein and polysaccharide fractions of the serum studied by paper electrophoresis. The following results were obtained.

1) Serum protein fraction: From about the 16 th week after infection, $\beta$-globulin increased and albumin decreased. When divided into the leproma group and the ulcer formation group this finding was more marked in the latter. In the group in which leproma could not be observed macroscopically, that is, the "spontaneous cure" group, the values were close to normal. From about 10 months after infection, an increase in $\alpha$ globulin was found and there was a marked increase in the ulcer group at 12.5 months.

2) Serum lipoprotein fraction: A marked increase in $\alpha$-lipoprotein was found in both liproma and ulcer groups but the pattern differed slightly between the two. This finding is present 10 months after infection.

3) Serum protein-bound polysaccharide fraction: A marked increase in $\alpha$-polysaccharide was found after 7 months in the ulcer group but there was no marked increase in the leproma group.

\section{鼠瀨感染マウスの血清蛋白分劃について}

\author{
須子田 キ \\ 東京女子医科大学細菌学教室（主任 平野害正教授）
}

（1958 年 7 月 28 日 受稿）

先に須子田は鼠瀨マウスの治療実験(1) 及び鼠瀬死菌ワ クチンによる発㱏阻止実験 ${ }^{2}$ の際のこれら被検動物の血 清蛋白分劃について報告した。これらの実験の結果，対 照として用いられた無処置の鼠瀨マウスの血清蛋白像は 感染後の時期によつて，又接種部の症状によつて差異の あることが認められたので，本実験においては，鼠瀬菌 をマウスに接種し，遂目的に又他方には感染後，同一時 期において，症状の異るものを大別して，それぞれの血 清蛋白分劃を行い，又同一血清については，糖筫及び脂 質の各分劃を㴔紙電気泳動法によつて検討し，鼠瀨マウ スの血清蛋白分劃の基礎的実験を行つた。
実 験 方 法

体重20 $\mathrm{g}$ 前後のdd系マウスに, 鼠癩マウス(ハワイ株) 結節の 100 倍乳刋を $0.2 \mathrm{cc}$ ずつ, 右胸部皮下に接種し, 初期には $3 \sim 5$ 週目毎に後には $2 \sim 3$ 力月毎に, 12.5力 月の間，心㶓穿刺によつて採血して実験に用いた。感染 後16週目までは感染群は严べて結節它有し, 潰瘍は未だ 形成さ机ていなかつた。これらの内より結節の大きさの ほぼ相等しいものを集めて一つ一つの郡とした。その内 第10週目の感染群は大凡, 小豆大の結節を有し, 第16週 目のものは大豆大以上, 母指頭大に及ら゙ものであつた。 
第20週目の感染群には小潰㾕を形成するものが羿められ たのでこ礼らは別に一群として潰暗群とした。第25週 以後に於ては潰瘍の大きさも次第に増大したので, ほぼ 同じ程度のものを集めて一群とした。第10力月目にこ机 ら感染群の中に，殆ど結節を触診し得ないマウスが 4 味 存在したのでこれらは一忘 “自然治痛”群として扱つ た。対照としては年令の差異による血清蛋白分劃の変動 をさけるため ${ }^{22}$ 同時購入の未接種の健康マウスの血清が 用いられた。各群の血清はいずれも採血後直ちに分離さ れ，前回までの実験と同椂に，泳動直前に，同一群数匹 のマウスの $0.1 \mathrm{cc}$ ずつの血清が混合されて用いられた。

血清蛋白分劃のための畓紙電気泳動法は, 前回までと 同様であつたので省略する。

血清蛋白結合糖啠の泳動法としては，第10力月目立で のものは，滤紙巾 $2 \mathrm{~cm}$ に $0.01 \mathrm{cc}$ ずつの血清を整布した が，12.5力月目のものでは, 分劃像をより明瞭にする目 的で, $0.03 \mathrm{cc}$ ずつを整布した。その他の泳動条件は前 と同様であつて, 呈色法としてはすべて Schiff の試薬 を用いた。

血清蛋白結合脂質の分劃の為には，第10力月目までは 滤紙巾 $2 \mathrm{~cm} 0.02 \sim 0.025 \mathrm{cc}$ ずつの血清空塗布し,Sudan 黒の $60 \%$ エタノール飽和液の 2 倍稀畍液で 3 時間染色を 行い, 水洗には, 初めの1〜2回は50\%エタノールだ, 後に流水で数時間洗つた。又蜕付は $120^{\circ} \mathrm{C}$ の高温で行つ たが，いずれも分劃が不明瞭であつた。そ放 12.5 力 目のものでは, 血清の量は $0.04 \mathrm{cc} / 2 \mathrm{~cm}$, 染色液の濃度 も稀丵せず飽和液のままを用いた。又水洗も，アルコー ルによる脂質の溶出芘防ぐため流水のみとし, 更に蛢付 けも高温をさけて，パフィンの温度を $90^{\circ} \mathrm{C}$ として泖 紙標本を作製した。

なお，鼠瀨感染マウスと健辰マウスとの血清蛋白分劃 值の差異がこ机ら両群の血清蛋白の総蛋白量, 及び血清 の溶血の程度の差異によつて影響を受けることがあるか も知机ないと考光, 総蛋白量は蛋白屈折計により, 溶血 の程度の差異は肉眼的に計測して参考とした。

\section{実 験 成 績}

鼠癩菌をマウスに接種した後， $3 ， 6 ， 10 ， 16 ， 20$, 25 週と, 7.5 力月, 10 力月, 12.5 力月目に採血し, これ らの分離血清について洃紙電気泳動法を行つた。その結 果次のような成績を得た。

血清蛋白分劃の成績 :

表及び図 $I_{1-3}$ に示すように，鼠瀨マウスにおいては， 感染後，16週目頃より，Albuminは減少し，ほぼ同時期
Table Electrophoretic distribution of serum protein of leprous mice

\begin{tabular}{|c|c|c|c|c|c|c|c|c|}
\hline \multirow{2}{*}{$\begin{array}{l}\text { Weeks } \\
\text { months }\end{array}$} & \multirow{2}{*}{$\begin{array}{c}\text { Number } \\
\text { of } \\
\text { animal }\end{array}$} & \multicolumn{5}{|c|}{ Serum Protein fraction $(\mathscr{O})$} & \multirow{2}{*}{$\begin{array}{c}\text { Total } \\
\text { protein }\end{array}$} & \multirow{2}{*}{ hemolyse } \\
\hline & & $\mathrm{Al}$ & $\alpha 1$ & $\alpha 2$ & $\beta$ & $\gamma$ & & \\
\hline $3 \mathrm{~W}$ & 7 & 46.2 & 8.5 & 8.6 & 19.5 & 20.5 & & \\
\hline normal & 7 & 41.0 & 9.3 & 10.3 & 18.6 & 20.0 & & \\
\hline $6 \mathrm{~W}$ & 6 & 50.0 & 9.5 & 8.2 & 17.2 & 16.3 & $5.8-6.8$ & \pm \\
\hline normal & 5 & 49.0 & 8.1 & 8.5 & 16.5 & 16.9 & $5.2-5.8$ & \pm \\
\hline $10 \mathrm{~W}$ & 6 & 53.0 & 8.3 & 7.5 & 18.4 & 12.8 & $5.4-6.0$ & \pm \\
\hline normal & 8 & 52.0 & 8.7 & 7.8 & 17.0 & 14.2 & $5.8-6.8$ & \pm \\
\hline $16 \mathrm{~W}$ & 8 & 47.2 & 7.4 & 7.0 & 24.1 & 17.1 & 6.8 & \pm \\
\hline normal & 8 & 53.0 & 7.1 & 6.7 & 18.8 & 14.2 & 6.8 & \pm \\
\hline $20 \mathrm{~W} \quad \mathrm{~T}$ & 4 & 51.0 & 10.7 & 7.8 & 17.0 & 9.3 & 6.5 & - \\
\hline & 4 & 51.0 & 11.0 & 7.7 & 21.5 & 8.6 & 6.2 & \pm \\
\hline normal & 4 & 51.5 & 10.5 & 7.9 & 18.5 & 12.1 & 6.5 & \pm \\
\hline $25 \mathrm{~W} \quad \mathrm{~T}$ & 7 & 41.1 & 6.1 & 5.9 & 20.0 & 20.9 & & \\
\hline & 3 & 39.0 & 8.0 & 8.7 & 26.2 & 18.0 & & \\
\hline normal & 3 & 52.0 & 11.3 & 5.0 & 14.4 & 15.3 & & \\
\hline $7.5 \mathrm{~m} \mathrm{~T}$ & 5 & 40.5 & 9.1 & 7.4 & 24.8 & 18.0 & 6.8 & \pm \\
\hline $\mathrm{U}$ & 8 & 34.5 & 8.3 & 9.9 & 27.8 & 19.3 & 6.8 & \pm \\
\hline normal & 6 & 47.7 & 8.9 & 7.8 & 17.9 & 17.9 & 7.0 & \pm \\
\hline $10 \mathrm{~m} \quad \mathrm{~T}$ & 7 & 37.2 & 8.3 & 10.8 & 23.3 & 20.7 & 6.5 & + \\
\hline $\mathrm{U}$ & 4 & 35.5 & 10.2 & 7.7 & 30.0 & 16.7 & 6.5 & \pm \\
\hline sp. cure. & 4 & 42.5 & 7.2 & 7.2 & 18.9 & 24.0 & 6.5 & + \\
\hline normal & 8 & 46.0 & 5.3 & 5.6 & 20.0 & 23.0 & 7.0 & \pm \\
\hline $12.5 \mathrm{~m} \mathrm{~T}$ & 1 & 32.0 & 7.8 & 10.0 & 21.5 & 27.5 & & \pm \\
\hline $\mathrm{U}$ & 1 & 25.2 & 6.5 & 16.6 & 26.2 & 26.3 & & \pm \\
\hline normal & 2 & 38.0 & 9.7 & 8.7 & 21.3 & 22.0 & & + \\
\hline
\end{tabular}

より， $\beta$-globulin の増加が認めら机た。第20週以後結節 群と潰瘍群に分けて観察したものでは，潰瘴群の方に， 常により著明に $\beta$-globuli の増加が認められた。 $\alpha_{1}$-, 及び $\alpha_{2}$-globulin の増加は, 感染後, 約 10 力以以後に, 結節群及び潰疾群の双方に認められた。12.5力月目の潰 瘍群においては， $\alpha_{2}$-globulin の増加が特に著明であつ た。 $\gamma$-globulinに扮いては感染後, 時期を異にしても, また症状別に観祭しても著明な変化は証明されなかつ た。

鼠瀨マウスの血清の総蛋白量は, 感染後, 7 力月半以 後においては正常マウスのそれに比べてやや低下与るよ うであるが，この範囲の差異では有意とは思われない。 （表） 
Fig. I-1 Electrophoretic change of serum albumin in mice after infection

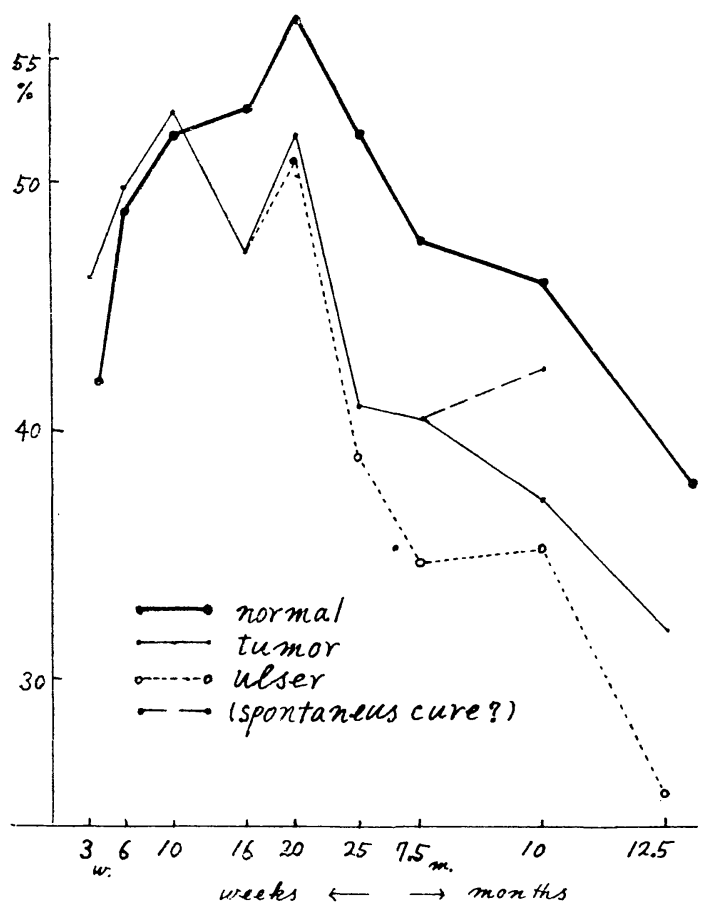

Fig $I_{-2}$
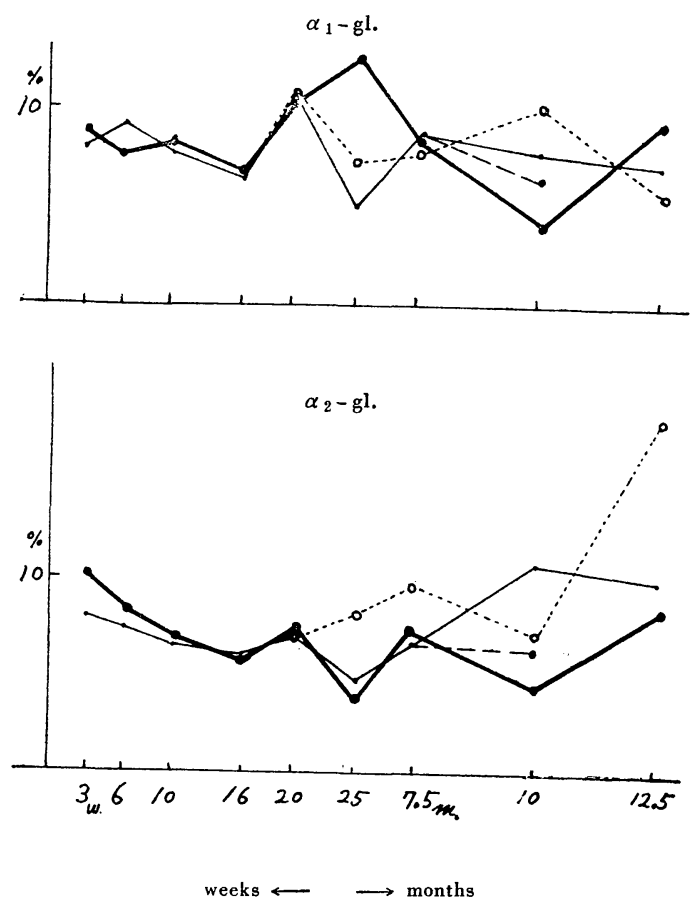

Fig. $\quad \mathrm{I}-3$
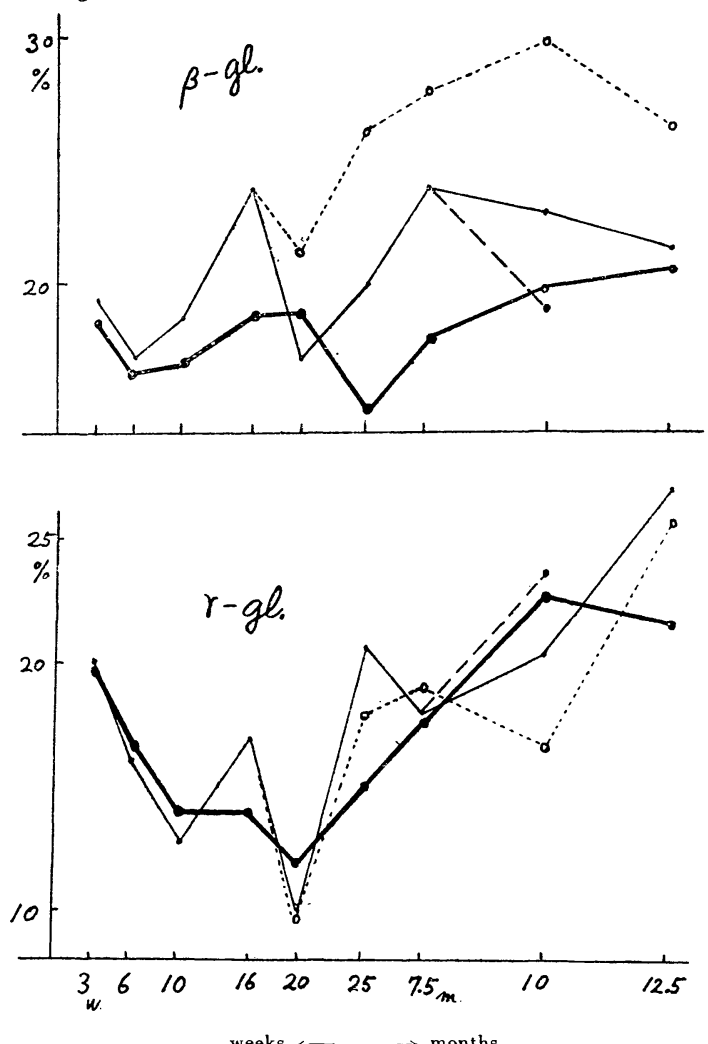

また本実験においては高度の溶血を示したものをすべ て除外したので，表に示すような軽い溶血の程度の範囲 では, 血清分劃, 特に $\beta$-globulin の変化に何ら影響を 及ぼしてはいない。

また 12.5 カ目の被検動物数は，感染群では夫々 1 匹 ずつであつた。小動物の血清蛋白分劃は個人差が甚しい という報告3) も㐫るが，感染後10力月までの被検動物数 はすべて 3 〜 8 匹でそれ等のマウスの血清を pool したも のが滤紙泳動に用いられ，その分劃成績と，感染後 12.5 カ月目のマウス血清のそれとを比較すると, 各分劃の変 化はほぼ同様の傾向定示し， $\alpha$-globulin 及び $\beta$-globulin の増加は10力月目より引続き認められた。(図 II 1-2)

感染後10力月目に実験された“自然治痛”群には肉眼 的には䍹結節は認められなかつたが，皮下組織，筋肉等 の塗抹染色には少数ではあつたが; 定型的な globi 含 さ攋菌が認められた。これらの血清蛋白分劃像は健康、 ウスのそれとほぼ近い值を示した。

血清蛋白結合脂質分劃の成績:

図而は感染後10力月目及び12.5力月の脂質の分劃像で あつて, その内, 後者のものについてみると, 結節群に 
Fig II-1 Paper-electrophoretic patterns of serum proteins of leprous mice

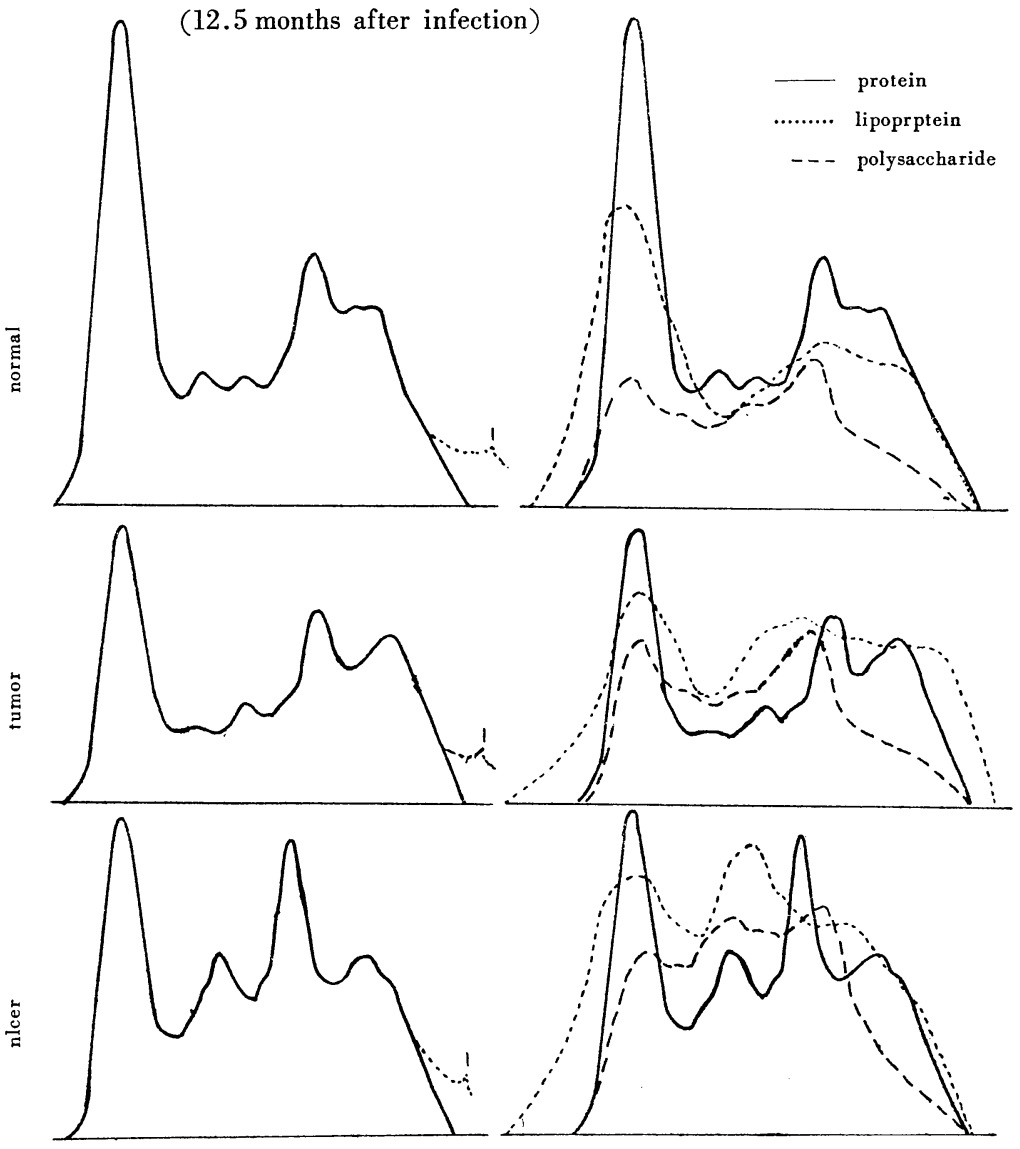

Fig II -2 Paper-electrophoretic patterns of serum proteins of leprous mice (10 months after infection)

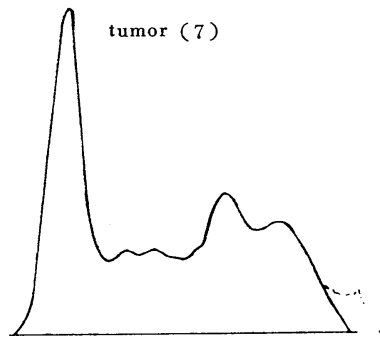

normal ( 8 )
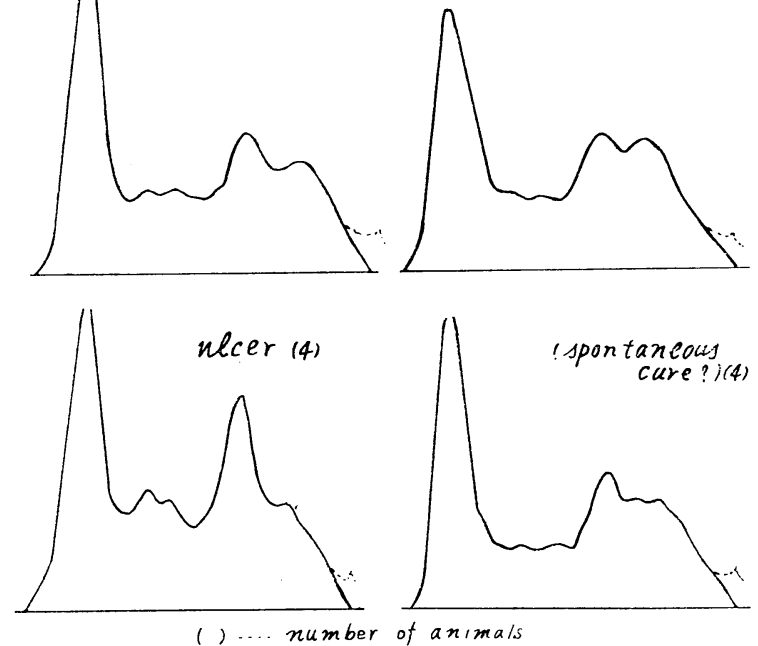
Fig III Paper-electrophoretic patterns of serum lipoprotein of leprous mice
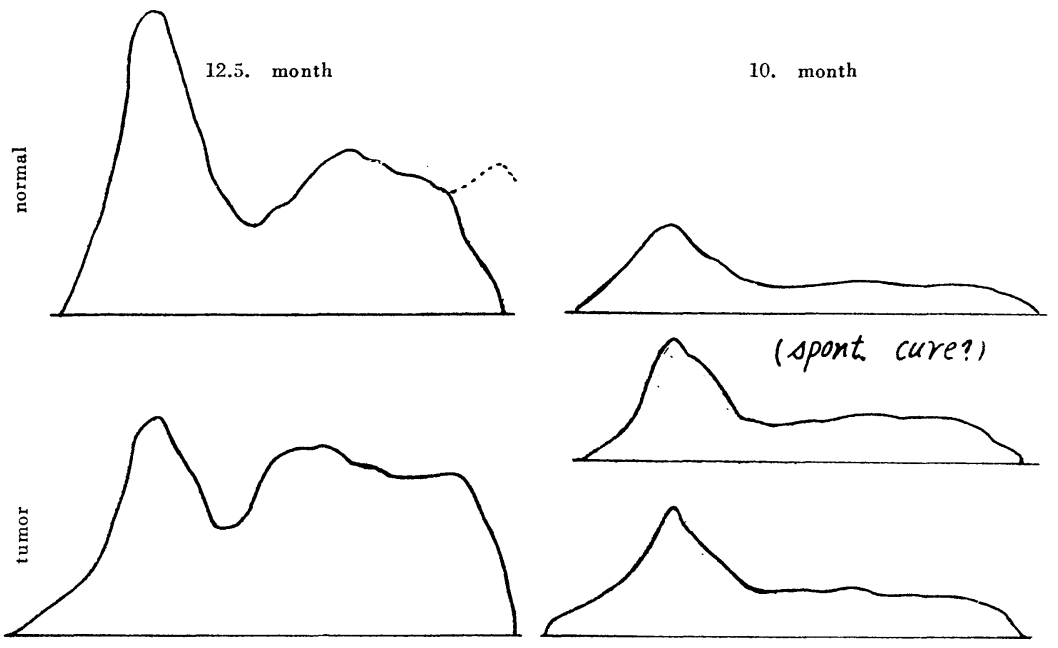

(spont cure?)
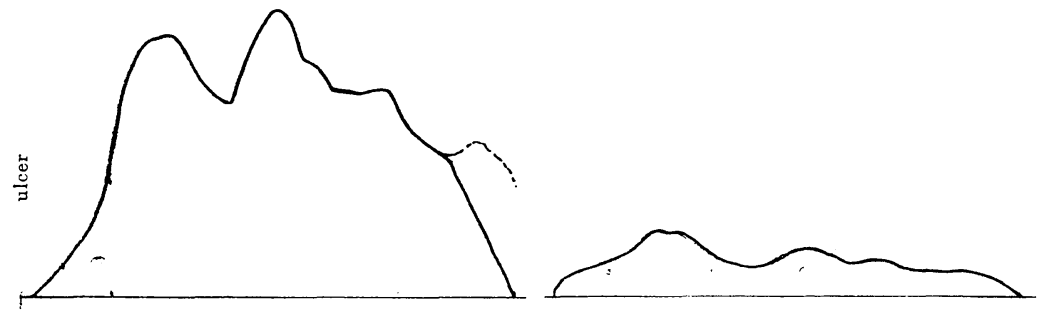

おいても，潰瘍群においても，共に $\alpha$-globulin の著明 な增加が認められる。し兄し画群の山の高まりはやや異

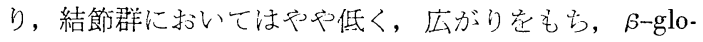
bulin 側が高くなつているが，皟湟群では亮まりは鋭く Albumin 側に片寄つている。但し両者の $\alpha$-lipoproteinの 計測值はほぼ等しく，大凡32.5\%であつた。こ机に反し て，健亦、ウスのそ机は（戍孟左上）17.9\%であつたか ら，鼠瀨、ウスにおける $\alpha$-lipoproteinの增加は藷明であ ると思う。しかしながらこの脂質の变化の出現劣る時期 については, 前に述べた如く, 血清の㻎が少量であつた こと, 及びその他の理由で鮮明な分劃像在得ることが出 来ず, 図亚右側に示したように感染後10力月目のもので は潰痗群においては， $\alpha$-lipoproteinの高まりを認めるこ とが出来るが平坦な広がり定示した絬節群では，全く不 明瞭であつた。しかしながら少くとも10力月頃には脂質 の增加は出現するものと考えられる。

血清蛋白結合䌅臀分劃の成績:

应IVは感染後10力月目及び12.5力月目の泳動図であつ て, 結節群における血清蛋白結合糖䓄惧は健康マウスのそ れに比べて殆ど変化を示さなかつたが，潰瘍群に打いて は, $\alpha$-polysaccharide の増加が著明であつて, かかる増

Fig IV Paper-electrophoretic patterns of serum polysaccharide of leprous mice

12.5. month

10. month
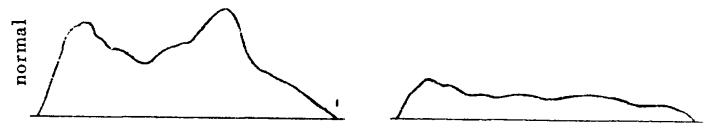

(spont. cure?)
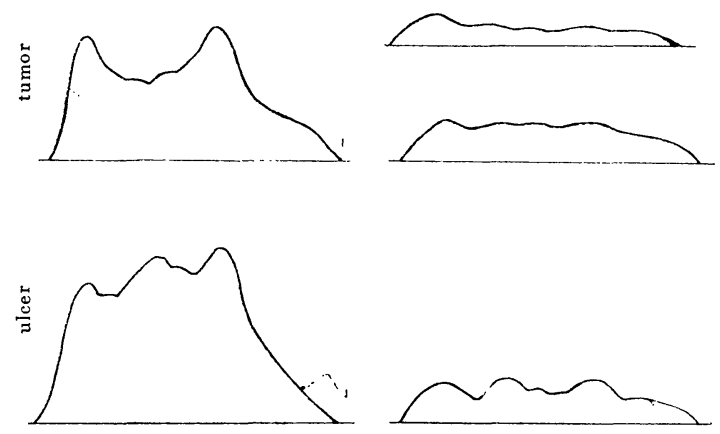

加の傾向は 7 力月目頃より明らかに出現しているのが認 あられた。 


\section{考案}

本研究においては，鼠㴼菌（ハワイ株）をマウスに接 種し,これらの鼠瀨マウスの血清蛋白, 脂質, 糖貿につ いて感染後の日数の差舆浡よる変化及び症状による差異 空観察した。

人の結節瀬においては， $\alpha$-globulin の增加が著明に認 められる事が多くの学者によつて報告されている。（石 原 ${ }^{4} 7$ ), 坂 $\square^{8)}$, 河野9), 難波 ${ }^{10)}$, 高橋11), 福(代12), 真 山 ${ }^{13)}$ ，及び Seibert ${ }^{14)}$ ) これらの啹告による上，重症例 程, 著明に增加し, 宝た $\beta$-globulin の增加（坂口, 難 波，谷墺，河野）与るももあるいう。

しかしながら鼠瀨についての報告は少なく, 鼠獺感染 ラッテについて重松 ${ }^{15}$ ，西村 ${ }^{16}$ ，の報告があるが，いず

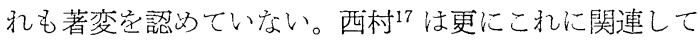
鼠顆では血清反応も除性であると述べている。鼠蹜てウ スについての血清蛋白分劃の実験は, 先に著者等が報告 した如く ${ }^{11}$ ， 鼠瀨感染、ウスにおいては $\beta$-globulin の增 加が著明で，これらのマウスは比較的早期に化学療法定 開始して治癒せし禹ると, 殆ど正常マウスの值にもどる けれども, 重症例においては化学療法によつて, 軽快せ しめ得たものでも，こ机らの血清蛋白分劃值についてみ ると, $\beta$-globulin 泟常マウスのそれよりは高いが,未治 療の鼠澒、ウスのよれより減少を示し, 他方 $\gamma$-globulin が僅かながら上昇する傾向を示していた。

また加熱, オレーフ油, 或いは流動パラフィンによつ て鼠瀨菌の死菌ワクチンを作つて，マウスに接種して疫 度し, こ机に感染陚験学行つた場合に, 最も発症阻止の 顕著であつたもの程， $\alpha$-, 及び $\beta$-globulin の増加するこ とが認められた2》。

本実験においては鼠瀨、ウスについての基濋的研究と して, 血清蛋白分劃を行うと共に, 之ら複合蛋白分劃の 変化に影響を与えると考无ら机る血清蛋白結合脂質及び 糖質の分劃を試みたが，上に述べた実験成績から，鼠瀨 マウスは, 鼠瀬感染ラッテ及び人霜とは異つた血清蛋白 像を示すことが明ら尔となつた。

結核症の場合の血清蛋白分割伛ついての報告を参考之 すると，本症に执いては， $\gamma$-globulin が增加するという

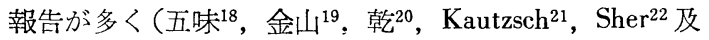
び Seibert $\left.{ }^{23}\right), \beta$-globulinの増加注, 臨床的にはKautzsch によると，合併症を伴うような場合に認められるとい う。又実験的には Seibert 注ウサギの結核症で，Sher は モルモットに抢いてこれを認めている。 $\alpha$-globulin は Shaw ${ }^{24)}$ によると結核その他の悪性疾患において増加す
るといい。Kautzsch は進行性結核に特に增加する上述 ベている。

以上のように癩或いは結核のような慢性疾患において は $\gamma$-globulin の増加が著明であつて (Sunderman ${ }^{25}$ ), $\beta$-globulin, 或いは $\alpha$-globulin は一般に瞦性のものに增 加与るようである。

本実験の結果によると，鼠瀨マウスに抢いては，感染 後, 比較的早い時期より， $\beta$-globulin の増加が出現し, 潰暗を形成するものでは，より一層その変化が著明であ つた。 感染後約10力月上り増加を示し浿㵓群の力が著明に変化 した。

之ら $\alpha-$, 及び $\beta$-globulin の增加の一因として, $\beta-$ globulin は lipoprotein の (荒木 ${ }^{26)}$, 藤田 ${ }^{27)}$, 幾島 ${ }^{28}$, 及 び LLoyd ${ }^{29)} ， \alpha$-globulin は polysaccharide の增加仁上 るものである（荒木，藤田）と考えられている。

しかしながら，真山 ${ }^{13}$ は は人顆嗅清について $\beta$-globulin の高値は認站ら机ないにも拘らず， $\beta$-結合脂質は增加 し, また藤田沙 $\beta$-lipoprotein の増加を伴わ放 $\beta$-globulin の増加の西る事（肝炎，シモンズ氏病）を認的ている。

本実験においても立な感染後, 16 週目頃から $\beta$-globulin の増加㳉認めらたが， $\beta$-lipoprotein の増加が認められ ずむしろ $\alpha$-lipoprotein の增加が認められた。結節群 と潰憻群に㧍ける $\alpha$-lipoprotein はほぼ相等しい值をも つて, 双方共に増加を示したが，泳動距離は両者共注ぼ 同じでありながら，前に述べたように山の型は異つてい た。

Seibert ${ }^{30)}$ 注 $\alpha_{2}$-polysaccharide 注結核气の他進行性の 疾患において增加を示与之述べ，Sher ${ }^{31)}$ もまた実験的 結核のモルモットにおいて， $\alpha$-globulin の Carbohydrate がやや増加するが, $\gamma$-globulin の増加に拘らず， $\gamma$-glo。 bulin の Carbohydrate 汇低下する之報告している。

本実験において， $\alpha$-globulin 注潰瘍群においても， 結節群においても共に增加し， $\alpha$-polysaccharide は潰 演群において著明汇增加し，結節群においては步まり著 明でなかつた。 $\alpha$-polysaccharide の増加は組織の崩壊 (荒木 ${ }^{25}$ ，Seibert ${ }^{30)}$ ) によつて起ると考えられているこ とと一致するように思わ机る。従つて鼠洯頁マウスの血清 蛋白分劃に打ける $\beta$-globulin の増加は lipoprotein の増 加を伴わ收 “ pure” protein のみの増加であると思わ机 る。(図 III 1 右側)

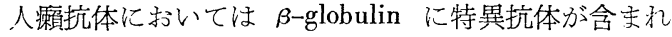
る（緒方32 33） と報告さ机ているが，鼠瀨マウスに挹 いては, $\beta$-globulin が増加しても $\beta$-lipoprotein の增加 
を伴わない。従つて結節のみを有するものより潰演を形 成したものの方に $\beta$-globulin の著明な増加が羿められ， またさきに報加したように，ワクチンによる感染防禦試 験にお顸ては，Olire 油ワクチンの效果が最も優れてい たが，この場合に拈いても， $\beta$-globulin が，他のワクチ ン觉接種したものよりも高い值を示したのでここ秃等の 場合に才ける $\beta$-globulin の増加は, 鼠瀨抗体の増加のみ とは思わ机ない。

潰济群における $a$-globulinの増加は結節群のそれより 著明であつたことは， $a$-polysaccharide及び $\alpha$-lipoprotein の雨者の増加の影響と考光られ，結節群における $\alpha$-globulin の増加は， $\alpha$-polysaccharide の壃加が, そ机程著 明でなふつたので， $\alpha$-lipoproteinの増加のみの影響と思 われる。

\section{結論}

マウスに鼠瀕菌を感染せしめてから，一方には逐月的 に他方には症状別に，これら鼠瀨、ウスの正清蛋白，脂 貿，糖質の分劃定行つた。

その結果次のような成績を得た。

1）血清蛋白分劃においては感染後約 16 週目より $\beta$ globulinの增加妿出現し，Albumin は減少炎示した。結 節群上潰㾤形成群上に分けて観察すると, 後者の方がこ 虬らの变化は著明であつた。文肉眼的には結節定認心ら

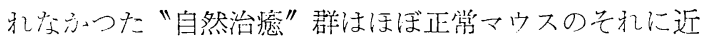
い值を示した。感染後約10力月以後において, $\alpha$-globulin の増加が誌心ら机，12.5力月目の潰瘍群に出いては，よ り著明な增加が証明された。

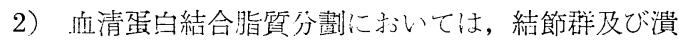
瘍群共，ほぼ同じ程度に， $\alpha$-lipoprotein の増加が著明に 認以られたが，Pattern には闭者にやや相異があつた。 これらの変化注感染後 10 力目に考でに出現した。

3）而清蛋白結合楉質については，潰疸群に尔いては 大凡感染後 7 力月頃より $a$-polysaccharide の著明な増加

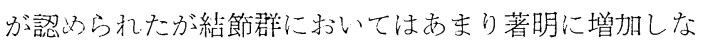
かつた。

終りに，平野憲正教授の御指導御校閲艺深謝し，併せ て種々御教示下さつた東京医科翻科大学小林茂三郎助教 授に謝意堂表すると共に研究生落合章雄氏の御援助を感 謝しま卞。

\section{文献}

1. 須子田キヨ：I NAH及び誘導体で治療した鼠瀨マ ウスの临紙電気泳動法による血清蛋白分劃について,

$$
\text { レプラ, 26, 249-254 (1957) }
$$

2. 須子田キヨ, 山田昇: 鼠瀨の免疫に関する実験的研 究, II 鼠癩死菌ワクチンで免疫したマウスにおける感 染防禦効果とその血清蛋白分劃像との関係について,

$$
\text { レプラ, 27, 263〜270（1958） }
$$

3. 平井秀松：血漿蛋白分劃法, 最新医学, 10, 105 122 (1955)

4. 石原重徳：癩の市清蛋白質に関する研究（第 1 報） レプラ, 19, (7) $3-11$ (1950)

5. 同上：同上（第 2 報），レプラ， 19, （7） 12 -18 (1950)

6. 同上：同上 (笴 3 報), レプラ, 19, (6) 7 $-10(1950)$

7. 同 上：瀨の臨床検杀 レプラ， 23, 163-164 (1954)

8. 坂口 弘: 瀨患者血清白㫮電気泳動図及び心電図に ついて, レプラ, 20, 60-61 (1951)

9. 河野通之, 他 2 : 濑性絓節性糽斑の血清蛋白組成並 びに白血球百分比について,

レプラ, 21, 98〜102 (1952)

10. 難波政士, 他 1 ：瀨の血清蛋白電気泳動分局像心関

与る研究，レプラ，21，237-239（1952）

11. 高橋竹代: 攋患者の赤血球涴降反応に関与る研究(5) レプラ, 23, 256-259 (1954)

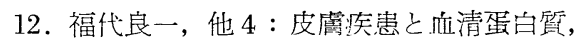
レプラ , 23, 215-225 (1954)

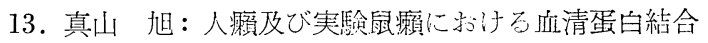
脂質について，レプラ，26，160-165（1957）

14. Seibert, B. F., et al: Electrophoresis of serum,

Am. Rev. Tub, 47, 66-77 (1943)

15. 重松 俊, 他 1 : 鼠瀨の発症とその血清分劃との関 係, レプラ, 20, 201〜202 (1951)

16. 西村真二, 他 1 ：鼠癩の血清蛋白組成について, レプラ, 21, 103-107 (1952)

17. 西村真二, 他 2 : 鼠瀨に打りる血清蛋白組成と血清 反忘の関連について, レプラ，22，327-328（1953）

18. 石味 二郎, 他: 結核症と血漿蛋白質, 生物物理化 学, 1, 149-160 (1953)

19. 金山晴夫：肺結核と血清蛋白, 生物物理化学, 1 , 171-184（1953）

20. 乾成美, 他 1 : 滤紙電気泳動法による肺結核の蛋白 像について, 結核, 31, (特別号) 30 (1956)

21. Kautzsch, E. : Filterpapierelektrophorese bei Lungentuberkulose, Münchner Med. Wochenschrift, 
98, 186-189 (1956)

22. Sher, C. B., et al : Serum protein change in experimental tuberculosis. Am. Rev. Tub. 77, 120-133(1958)

23. Seibert F. B., al: Electrophoretic study of the blood protein response in tuberculosis.

J. Biol Chem, 143, 29 (1942)

24. Shaw B. D., et, al : an Electrophoretic study of serum and pleural fluid proteins in chest deseases,

J. clin. path., 9, 251-254 (1956)

25 . Sunderman W. F., et al: clinical application of the fractionation of the serum protein by paper electrophoresis, Am. J. clin. path., 27, 125-158, (1957)

26. 荒木 仁: 血清蛋白分屑, 特に $\gamma$-gl. 分㞕に対する 考察, 最新医学, 10, 148 159 (1955)

27. 藤田伝太郎, 他 3 : 血清 proteino-lipidoglycogram に ついて, 生物物理化学, 3, 163-166（1956）
28. 幾島 明：内科矤患の血漿蛋白質

最新医学, 10, 189-201 (1955)

29. LLoyd A.G., et al : Electrophoretic partition of $\beta$ globulins in human sera by a non-ionic detergent,

J. clin. path., 9, 248-250 (1956)

30. Seibert B. F., et al: Variation in protein and polysaccharide content of sera in the chronic diseases, Tuberculosis, sarcoidosis and carcinoma.

J. clin. Invest., 26, 90-102 (1947)

31. Sher C. B., et al: Serum peoteiu-bound carbohydrates and lipids in experimental tuberculosis, Proc. Soc. Exp. Biol and Med., 93, 578 581 (1956)

32. 緒方富雄, 他: 瀨血清反応における抗体の諸性質, レプラ, 23, 221 (1954)

33. 緒方富雄, 他: 瀨血清の新しい血清学的反忘（第 4 報）日新医学, 43, 207-217 (1956) 